\title{
The politicization of crime: electoral competition and the supply of maritime piracy in Indonesia
}

\author{
Ursula E. Daxecker ${ }^{1}$ (D) Brandon C. Prins ${ }^{2}$
}

Received: 5 September 2016/ Accepted: 8 September 2016/Published online: 5 October 2016

(C) The Author(s) 2016. This article is published with open access at Springerlink.com

\begin{abstract}
Electoral competition in weak institutional settings has been shown to increase criminal violence, in particular homicides. Electoral competitiveness, by virtue of threatening the ability of incumbents to maintain informal corruption agreements with criminal networks, is argued to increase crime because of violent competition among criminal groups over future influence. We link elections to maritime piracy, a form of criminal behavior that has increased substantially since the end of the Cold War and for which cross-national, temporally and spatially disaggregated data are available. We argue that electoral competition reinforces piracy because political changes threaten to disrupt collusive agreements between pirates and government authorities. Anticipating a disruption of criminal activity, pirates elevate their attack rates before political changes undermine these agreements. This disruption effect suggests that jurisdictions holding competitive electoral contests should experience more maritime piracy. We test our hypothesis on electoral competitiveness and piracy with subnational data for the 1999 and 2004 elections in Indonesia. Our results show that piracy escalates in proximity to highly competitive electoral districts.
\end{abstract}

Previous versions of this paper were presented at the conference on the Political Economy of Political Violence, May 19-21, 2016, Dallas, TX, the International Studies Association meeting, March 16-20, 2016, Atlanta, GA, the Quantitative Seminar, March 17, 2016, Amsterdam, Netherlands and the European Conflict Network Meeting, January 21-22, 2016, Geneva, Switzerland. We thank the editor, two reviewers, Brian Burgoon, Wouter van der Brug, Hanne Fjelde, Michael Gilligan, Francesco Moro, Todd Sandler, Seiki Tanaka, Nina von Uexkull, and conference participants for comments.

Ursula E. Daxecker

u.daxecker@uva.nl

Brandon C. Prins

bprins@utk.edu

1 Department of Political Science and Amsterdam Institute of Social Science Research, University of Amsterdam, Postbus 15578, 1001 NB Amsterdam, The Netherlands

2 Department of Political Science and Howard Baker Center for Public Policy, University of Tennessee, Knoxville, 1001 McClung Tower, 1115 Volunteer Blvd, Knoxville, TN 37996, USA 
Keywords Maritime piracy · Electoral competition - Collusive agreements - Spatial models $\cdot$ Crime $\cdot$ Indonesia

JEL codes D02 $\cdot \mathrm{D} 72 \cdot \mathrm{K} 42$

\section{Introduction}

Elections in unstable or formerly illiberal regimes often are accompanied by significant political and criminal violence, which has potentially deleterious consequences for democratic consolidation. The political science literature has linked elections to various types of political violence, yet comparatively little work has explored whether elections influence the activities of criminal groups, i.e., violence without clear political goals. Important contributions by Villarreal (2002) and Hoelscher (2015) argue that the prospect of electoral competition induces violent bargaining between criminal groups over future influence. Evidence from Mexico and Brazil shows that elections, especially if competitive, increase the incidence of homicides (Hoelscher 2015; Villarreal 2002). However, we do not know whether these findings on homicides hold for other types of crime or in other national and regional contexts. In this paper, we hypothesize a link between elections and maritime piracy, a form of crime that has yet to be connected authoritatively to electoral processes. We argue that competitive elections are associated with more piracy because political rivalry threatens to disrupt existing collusion between criminal actors and local elites. Evidence from Indonesia supports this conjecture.

Our paper makes three contributions to research on competitive elections and violence. First, we provide one of the first systematic, subnational assessments of the relationship between electoral competition and piracy. Some observers note that piracy increased during Indonesia's first democratic elections in 1999 (e.g., Amirell 2008), but do not explore it further. ${ }^{1}$ Gaibulloev and Sandler (2016) examine the effect of decentralized governance on piracy, including the holding of bottom-tier elections, but do not assess the explanatory power, if any, of electoral competitiveness. We use subnational data on electoral competition and piracy for the first two democratic elections in Indonesia, held in 1999 and 2004, to examine that link systematically. Our findings show that offshore areas close to competitive electoral districts experience more piracy. In addition, cross-national analyses covering the 1993-2010 period establish a positive effect of electoral competition on piracy for a global sample. While these latter results are weaker, both analyses suggest that piracy is linked to electoral processes, which broadens the empirical relevance of the election-crime link. Second, we extend existing work on elections and crime by establishing how the anticipated disruption of governing coalitions by competitive elections increases criminal activity. A limitation of the emphasis on homicides in existing work is that murder rates are seen as indicators of competition among criminal groups rather than criminal activity itself, which often remains unobservable. In the case of piracy, attacks indicate actual criminal activity (as well as competition between groups), allowing us to explore the effects of elections on crime more generally. We argue that elections threaten to disrupt existing patronage networks between pirates and politically relevant actors, producing incentives to increase piratical activity around elections before political changes

\footnotetext{
${ }^{1}$ Based on data from the Maritime Piracy Event and Location Data (MPELD), Indonesia experienced 140 incidents from 1995 to 1997, compared to 304 from 1998 to 2000, which includes the 1999 elections (Daxecker and Prins 2015a).
} 
could disrupt their relationships, but also to signal pirates' influence to local elites. This supply-centered argument suggests that piracy increases around elections, especially if competitive, which we corroborate in empirical analyses. A third contribution of our paper stems from the nature of the piracy data. Such information is based on reports from crew members, ship owners, and government authorities, which should make them less prone to over reporting during election periods than the media-based data commonly used in studies of political violence (Earl et al. 2004). An additional advantage is that piracy is unlikely to conflate criminal and political violence; distinguishing the two is more challenging with data on homicides.

We proceed as follows. We first review the literature on elections and political and criminal violence. We then develop our theory hypothesizing a disruption effect. Our empirical section consists of a subnational analysis of piracy in the 1999 and 2004 Indonesian elections. Robustness tests, including a cross-national analysis, confirm the importance of competitive elections as triggers of piracy.

\section{Elections and violence}

Elections offer peaceful means for contesting political offices, yet are often accompanied by significant violence. A growing literature links elections to low-level civil unrest, government repression, ethnic conflict, civil war and terrorism. ${ }^{2}$ Research suggests that electoral processes in weakly institutionalized settings produce political violence because the stakes are high, incumbents are concerned about holding onto power, and fragile political structures may not safeguard elite interests (Fjelde and Höglund 2016; HafnerBurton et al. 2014; Salehyan and Linebarger 2014). Others suggest a more nuanced relationship, arguing that weaker incumbents prefer using violence, while stronger ones use nonviolent forms of manipulation (Chaturvedi 2005; Collier and Vicente 2011). In contrast, Wilkinson's (2006) analysis of India argues that ethnic violence is less common when partisan competition is more intense because incumbents must cater to minority votes. Work on terrorism also emphasizes the use of violence to disrupt electoral processes or overthrow the status quo (Staniland 2014). Newman (2012) finds that terrorist incidents peak around election time, particularly in dictatorships, while Aksoy (2014) shows that terrorism increases around elections only in democracies with low levels of electoral permissiveness (i.e., low electoral system proportionality).

In comparison, the literature on elections and criminal violence is much less developed. If electoral competition in weakly institutionalized political environments fosters violence because it threatens elites' hold on power, then such competition similarly should threaten criminal networks fearing disruption by regime change. Collusion with political actors is crucial for the long-term viability of criminal organizations (Bailey and Taylor 2009), and impending upheavals threatened by electoral competition could thus lead to more criminal activity and violence. Villareal (2002), for example, argues that electoral competition and its potential to disrupt patron-client relations leads to greater homicidal violence in Mexico. Consistent with this expectation, he shows that rural municipalities, where voter support for the incumbent party was weaker, experience higher homicide rates. Similarly, Hoelscher (2015) hypothesizes that political competition threatens to disrupt coercive institutions used to protect political advantage and thus is linked to greater violence.

2 Related research examines how political violence, in particular terrorism, influences electoral processes (Berrebi and Klor 2006; Gould and Klor 2010). 
Municipal-level results from Brazil confirm the connection between elections, competitiveness, and homicidal violence (Hoelscher 2015). Outside of Latin America, Alesina et al. (2016) establish that electoral cycles lead to higher homicide rates in regions dominated by the Mafia. While focused on party structures rather than elections, Moro et al. (2016) argue that party fragmentation reduces criminal violence because it provides multiple access points for criminal organizations. Based on Italian evidence, Mafia killings rise during times of single-party dominance but fall when governance is fragmented. Moro et al.'s (2016) findings seem consistent with a competition effect-crucially, criminal activity increases when actors fear that their ability to engage in crime will be constrained. More generally, evidence on crime and elections also is consistent with arguments linking democratization to criminal violence, especially in the Latin American context (Grillo 2012; Kalyvas 2015).

In contrast, other researchers hypothesize a political crime cycle and argue that elections can be crime-reducing since political elites have incentives to crack down on criminals in the run-up to elections to convince voters they are "tough on crime" and raise their chances of reelection (Ghosh 2006; Gordon and Huber 2002; Meloni 2012). While this argument hinges on the assumption that concerns about crime are highly salient for voters, subnational analyses of Argentina and India in Meloni (2012) and Ghosh (2006) show a reduction in crime before elections because of more vigorous enforcement, although this effect is absent for violent crime.

The following section elaborates our mechanism linking elections to maritime piracy, a form of criminal behavior that has increased substantially since the 1990s.

\section{Electoral competition and maritime piracy}

Maritime piracy reemerged as a common form of criminal violence with the end of the Cold War. Compared to other crimes, such as robberies, rape, or homicides, piracy is geographically more limited since it occurs at sea or in ports. Yet piracy nevertheless affects many coastal states. Between 1993 and 2014, 97 of 177 states with coastlines experienced at least one piracy incident, 47 states experienced more than 10 incidents, and 13 states experienced more than 100 pirate attacks. Conceptually, many piracy incidents (particularly those occurring in ports) may be closest to armed robbery, although piracy can involve significant violence against crewmembers (or the threat thereof) and may also involve the capture of crewmembers, the hijacking of ships, or both, and then bargaining for ransom with foreign ship owners. Maritime piracy thus may be perpetrated by individuals engaging in sporadic, isolated acts, but can also involve small and medium-sized groups with substantial, hierarchical organizational structures (Hastings 2012). With two important exceptions (Gaibulloev and Sandler 2016; Shortland and Varese 2015), the scholarship on piracy has not yet examined whether electoral processes influence the behavior of pirate organizations. ${ }^{3}$ Existing research largely has focused on the roles played by weak institutions and the lack of legal employment opportunities in creating permissive conditions for piracy (Axbard 2015; Daxecker and Prins 2013, 2015b; Hastings 2009; Jablonski and Oliver 2013). We theorize a supply-side mechanism, arguing that elections influence pirates' incentives to engage in and to expand their criminal activities.

\footnotetext{
${ }^{3}$ Using cross-national and subnational data, Gaibulloev and Sandler (this issue) show that the holding of regional elections reduces piracy. We focus on the consequences of electoral competitiveness for piracy rather than the presence or absence of elections.
} 
Drawing on the extant literature linking elections and criminal violence, we expect that competitive elections threaten to disrupt agreements between pirate groups and local elites. Collusion between pirates and local governing authorities frequently has been identified as essential for the flourishing of pirate organizations since such connections help stabilize the environment in which pirates operate (Hastings 2012; Hastings and Phillips 2015; Murphy 2009; Shortland and Varese 2014). Hastings (2012, p. 689), for example, observes that incidents in the South China Sea essentially disappeared once the Chinese government cracked down on pirate-government collusion. Empirical studies of piracy in Africa and Southeast Asia have shown the importance of pirate group connections-whether through payoffs or other arrangements-with government actors (Hastings 2012; Hastings and Phillips 2015; Pérouse de Montclos 2012; Shortland and Varese 2014). In Indonesia, for example, corrupt customs officials, port employees, or crew members were known to provide information on ship movements and cargo manifests to pirates (Storey 2008). Further, during the New Order era in Indonesia, ties between criminal actors and various levels of the state bureaucracy served as a form of regime maintenance (Wilson 2006, p. 266). Given these connections between pirate organizations and local elites, pirates (and other criminals) might be concerned about the potential disruption of such networks by elections. These effects are particularly likely in areas where elections are competitive, especially so in the regions where pirates are active. Concerns about major political changes triggered by elections should thus translate into larger numbers of attacks because pirate groups are unsure about their future ability to manage operations. ${ }^{4}$.

In contrast to existing work on elections and crime, we do not anticipate that preelection increases in piracy can be explained by pirate groups competing violently with one another over future political influence on government officials in electorally competitive areas. Nor do we think that such violence primarily is meant to suppress competing pirate groups. While some of the rise in piracy may be the result of more vigorous intergroup competition, we also believe that pirates elevate their attacks because they fear electoral interruption of their connections with incumbent politicians and public officials. This supply-centered argument focuses on the bargaining relationship between local political elites and pirate organizations. The threat to target ships travelling to and from a country's port facilities provides leverage with local officials who fear disruption of ship traffic. Port charges remain important sources of government revenue in many countries and shipping companies rationally avoid sea lanes and anchorages where the risk of piracy is too high. In principle, a stable equilibrium rate of piratical activities maximizes both profits for pirates and rents for local elites.

The rate of pirate attacks is a choice variable for pirate organizations. Elevating the frequency of piracy demonstrates local pirate groups' prowess and increases leverage in bargaining and collusion around election time, especially if a new regime is expected to prevail at the polls. On the other hand, pirate groups will maintain the status quo ante level of violence if incumbents are expected to win. Piracy thus is thus expected to rise before

\footnotetext{
4 An observationally equivalent explanation would be that voters punish incumbents who are unable to reduce crime, leading to a negative association between victory margins and piracy. We think this is unlikely for two reasons. First, we do not think that voters' perceptions of the government's counterpiracy efforts matter early on in the democratization process because citizens are preoccupied with other issues. For example, in a survey of Indonesian citizens following that nation's first democratic elections, only $7 \%$ of respondents identified crime as a significant concern, while the overwhelming majority thought economic issues were more important (Wagner 1999). Moreover, unlike other crimes, such as theft, robbery, or murder, piracy is less likely to affect negatively the daily lives of a large number of voters because its main targets are international or domestic ships, not small fishing vessels.
} 
and during competitive elections because those groups carry out more attacks in order to capture more prizes before their activities can be disrupted by a new governing regime, or to strengthen their bargaining positions with the incumbent regime if political equilibrium has not yet been reached.

In addition to the threat of disruption, pirate groups could also use income from piracy to support their preferred candidate(s). Research on Somalia has connected hijacked ship and crewmember ransoms to collusion between local politicians and pirates (Shortland and Varese 2015). A share of attack-generated revenue flows into the pockets of political elites who use the funds for campaign activities. ${ }^{5}$ After elections, piracy may continue at higher rates if the incumbent or the incumbent party loses office, leading to more piracy until new elites assume or consolidate power. Our first hypothesis thus specifies a direct effect of electoral competition on piracy.

Hypothesis 1 Electoral competition increases the incidence of piracy.

The foregoing theoretical rationale suggests that piracy should increase when electoral competition threatens current collusive agreements. In particular, these implications should hold during transitional periods when major political changes threaten existing patronage networks (Villarreal 2002). Once electoral competition becomes more routine and institutionalized, voter evaluations of incumbents' performance on crime may start to figure more prominently, which is why we expect that the empirical implications of our arguments are most pronounced in the immediate democratization period. The hypothesized association between elections and piracy could decline or even disappear once democracy is more established.

\section{Elections and piracy in Indonesia}

We test the empirical implications of our arguments with subnational data on the 1999 and 2004 Indonesian elections and piracy. A disaggregated analysis has several advantages, including allowing for an assessment of the effects of both national and regional elections, accounting for subnational differences in the competitiveness of elections, and fully considering the spatial variation in piracy incidents.

We choose Indonesia as the case for subnational analyses for two reasons. First, we purposely choose a country with pervasive piracy since the implications of our arguments should be most apparent where pirates are active historically and where organized piracy is present. Indonesia has experienced some of the most extensive and entrenched maritime piracy in the world, events that provide a testing bed for our argument expecting an escalation of criminal activity brought about by political changes (rather than elections causing piracy in the first place). ${ }^{6}$ Second, the 1999 and 2004 elections are useful cases with regard to effects of electoral competition on criminal behavior. Before the fall of Suharto in 1998, elections were not competitive and should not have affected Indonesian

\footnotetext{
5 The disruption mechanism emphasizes local and regional actors, suggesting that elections with important local or regional consequences should be more likely to trigger increases in piracy. In subnational analyses for Indonesia, we distinguish legislative and regional elections, and find effects for both. Our cross-national robustness tests include only national elections, not all of which may have important local-level effects, thus biasing the analysis against finding the hypothesized relationship.

6 Twenty-five percent of the incidents in the MPELD database from 1993 to 2014 occur in or near Indonesian waters.
} 
piracy materially. The 1999 and 2004 legislative elections were the first two democratic, multi-party elections in more than five decades and this prospect should have influenced the behavior of pirate organizations as hypothesized in our theory. ${ }^{7}$ State patronage during the Suharto regime permeated many layers of the government bureaucracy, including a symbiotic relationship between street-level criminals and military, political, and social elites (Wilson 2006, p. 266). The threat that political changes would disrupt those networks for pirate and other criminal actors thus was substantial. Importantly, both the 1999 and the 2004 elections led to major political realignment.

The 1999 legislative elections resulted in the defeat of the incumbent party Golkar (Suharto's party) by the newly formed opposition Indonesian Party of Struggle (PDI-P) in 18 of 34 provinces. Yet in the 2004 legislative elections, disappointment with the reformists produced victory for Golkar and the defeat of the PDI-P in a majority of Indonesia's provinces, meaning that both elections had significant consequences for criminal actors concerned with access to elites. While existing research on Indonesia has linked elections to piracy only anecdotally as being the result of changes in patronage networks (Amirell 2008), other work has pointed to the importance of political protection for criminal activity in that country (Choi 2007; Wilson 2006). Scholars also have noted that surges in criminal violence, including robberies, extortion, and gang violence, coincided with the end of the Suharto era (Welsh 2008; Wilson 2006).

Since subnational analyses of a single case do not allow for generalizing, we also present cross-national analyses of elections and piracy in robustness tests (Table 3).

\section{Research design}

\subsection{Data and variables}

Our unit of analysis for Indonesia consists of Peace Research Institute Oslo (PRIO) grids $(55 \times 55 \mathrm{~km}$ cells) within Indonesia's Exclusive Economic Zones (EEZs) (Tollefsen et al. 2012). ${ }^{8}$ Exactly 2340 grids fall within Indonesia's EEZs, which extends (up to) 200 nautical miles from its coastline. We choose Indonesia's EEZs rather than territorial waters since most accounts suggest that piracy in this area is committed by home-grown Indonesian pirates (Nautilus Institute 2007). Moreover, we add 27 grids in the Malacca Straits, lying outside of Indonesia's EEZs, since observers attribute these incidents to Indonesian pirates (Nautilus Institute 2007).

Our dependent variable measures the number of piracy incidents one year before, during, and after the 1999 and 2004 elections (i.e., 1998-2000 for the 1999 elections and 2003-2005 for the 2004 elections). To make sure that the inclusion of post-election piracy events does not drive these results, we also estimate a model omitting events in the year after elections (Model 2). Data for maritime piracy, the main dependent variable, come from the Maritime Piracy Event and Location Data (MPELD) (Daxecker and Prins

\footnotetext{
7 We focus on legislative elections because Indonesia did not have direct presidential elections until 2005. Legislative elections also are likely to have more significant local-level implications than presidential elections. Research on Indonesia highlights the important local and national-level role played by political parties, such as Golkar and the PDI-P (Slater 2004).

${ }^{8}$ PRIO GRID is available at http://grid.prio.org/\#/download. EEZ shapefiles come from http://www. marineregions.org/downloads.php. ArcGIS 10.3 was used to create the dataset and to calculate distance controls.
} 
2015a). ${ }^{9}$ These data include piracy incidents from the International Maritime Bureau (IMB). Using MPELD, we calculate the sum of piracy incidents for each EEZ grid in Indonesia. The variable ranges from 0 to 35 , and $4 \%$ of all grids experience one or more incidents. Our estimation method is negative binomial regression because our dependent variable is an event count with over-dispersion. We include grid-clustered standard errors in all regressions.

To test hypothesis 1, our key independent variables measure subnational electoral competition. We use province-level election results from the Global Elections Data for the 1999 elections (Brancati 2014) and constituency-level election results from the Constituency Level Election Archive (CLEA) for the 2004 elections (Kollman et al. 2011). ${ }^{10}$ We then calculate the margin of victory in each of the 34 provinces for the 1999 elections, and each of the 70 constituencies for the 2004 elections, respectively. The margin of victory is calculated by subtracting the second-place party's votes from those of the winner and then dividing this number by total votes in each province/district. Smaller values thus indicate more competitive elections. Because elections happen on land and piracy at sea (or in ports), we use ArcGIS to create buffers of the margin variable that extend to all EEZ grids. We then calculate average values for margin buffer variables for all grids. Margins range from 0.03 to 0.48 . The map in Fig. 1 shows Indonesia's provinces with election victory margins (with lighter shades representing smaller margins) and Indonesian EEZ grids for the 1999 elections. The black dots denote piracy incidents from 1998 to 2000 .

Figure 2 provides the same information for the 2004 elections. Indonesia's constituencies are shown with election victory margins (with lighter shades representing smaller margins) and surrounding EEZ grids. The black dots show piracy incidents from 2003 to 2005 . We note that piracy persists in some regions, in particular Riau, despite only intermediate levels of electoral competition in 2004.

Data for several control variables come from the PRIO GRID, version 2.0 (Tollefsen et al. 2012). To control for economic development, we include data on nighttime light emissions for the year before elections for all grids in Indonesia. For nighttime lights, we use a similar procedure with buffers as described for elections above. ${ }^{11}$ We do not include additional controls for GDP or population because these variables correlate extremely highly at the ocean grid level $(\mathrm{p}>0.95)$. We control for the number of ports on grids bordering Indonesia because access to ports is likely to be associated with greater pirate activity. ${ }^{12}$ We include data for rainfall in grids in the year before elections because excessive rains could reduce the potential for piracy, again creating buffers because the PRIO GRID does not include information for ocean grids.

We also control for average temperatures in the year before elections since higher temperatures could result in more crime. We include the distance between each grid and the coast as a standard control in all models. The statement that the origins of piracy are land-based is now a cliché in the piracy literature, but suggests that grids at greater

\footnotetext{
${ }^{9}$ In line with the IMB definition, incidents are counted if they meet UNCLOS's definition of piracy or the IMO's definition of armed robbery.

${ }^{10}$ For the 1999 elections we are limited to provinces, the first-order administrative units, because neither GED nor CLEA have more disaggregated results. Because CLEA does not provide a shapefile of the 77 constituencies in Indonesia, we created one ourselves by geo-referencing constituencies with maps available at the following website: http://www.seasite.niu.edu/indonesian/Indonesian_Elections/Districts04.htm.

11 DMSP OLS Nighttime Lights, data from http://ngdc.noaa.gov/eog/dmsp/downloadV4composites.html.

12 Observations are taken from the World Port Index, available at http://msi.nga.mil/NGAPortal/MSI. portal?_nfpb=true\&_pageLabel=msi_portal_page_62\&pubCode $=0015$.
} 


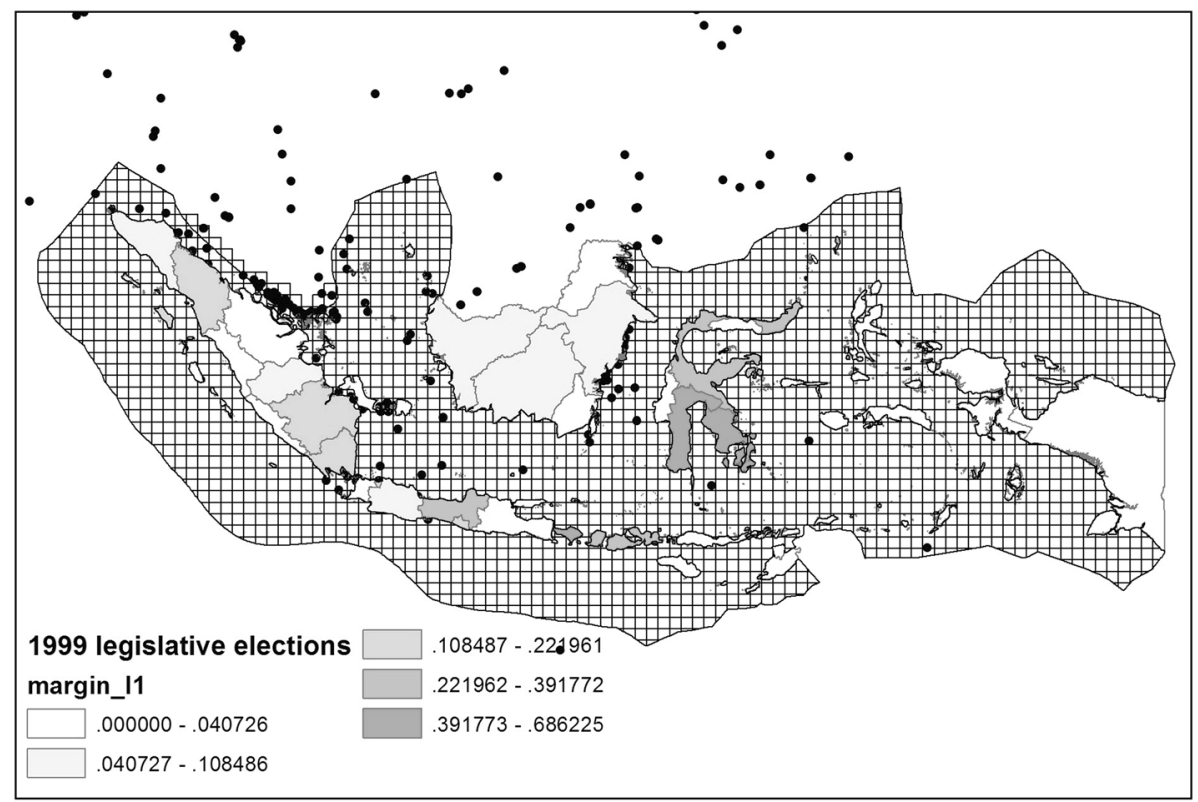

Fig. 1 Indonesia EEZ PRIO grids: 1999 election margins and piracy incidents

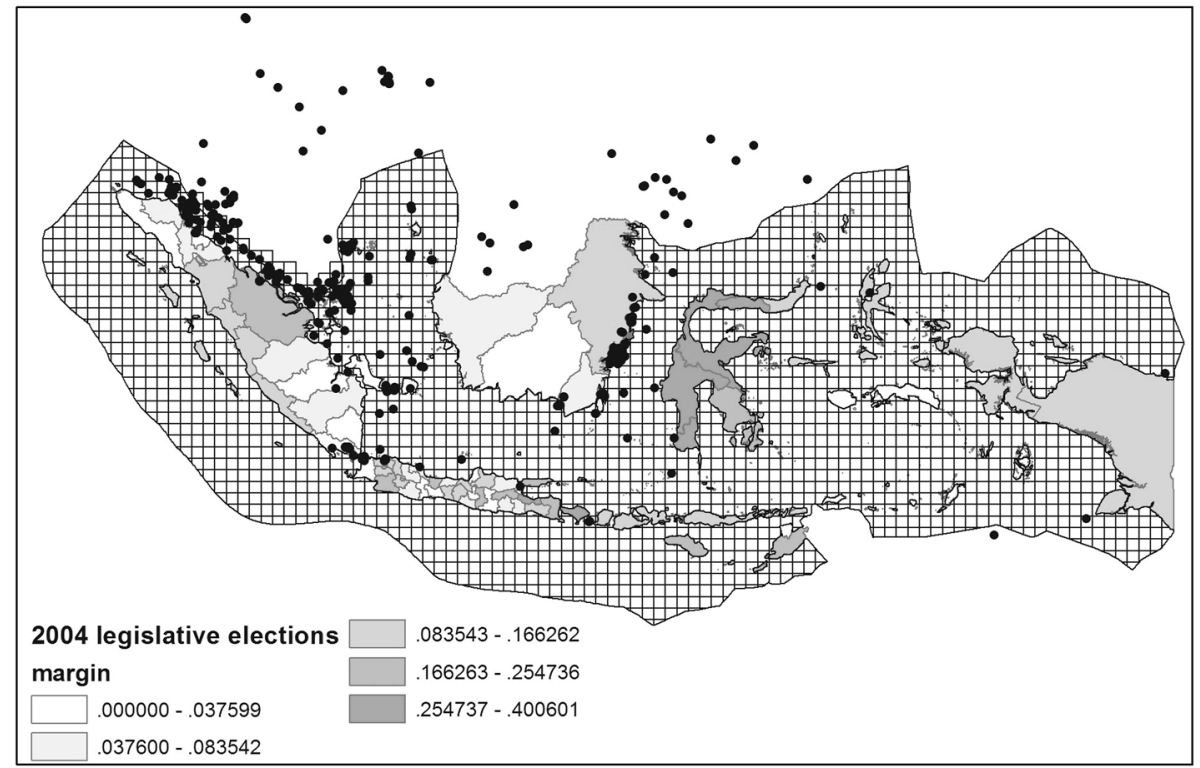

Fig. 2 Indonesia EEZ PRIO grids: 2004 election margins and piracy incidents

distances from the coast experience less piracy. The distance variable measures the kilometer distance between each grid and Indonesia's coastline, which we calculate in ArcGIS. The variable ranges from 0 (for grids adjacent to Indonesia's coast) to $369 \mathrm{~km}$. 
Furthermore, we include a dummy coded 1 for the 67 grids adjacent to the Malacca Straits (again calculated in ArcGIS), a major shipping chokepoint creating opportunities for piracy. Even a visual inspection of Figs. 1 and 2 makes the strong effect of this chokepoint on piracy in proximate grids apparent. We account for the temporal and spatial dependence of piracy. For temporal dependence, we calculate the average number of incidents in MPELD in each grid for 3 years preceding the measurement of our dependent variable (1995-1997 for the 1999 elections and 2000-2002 for the 2004 elections). For spatial dependence, we calculate a spatial lag of piracy based on grid contiguity. The variable ranges from 0 to 7 and measures whether the incidence of piracy in contiguous grids influences the risk of piracy in each cell. A final control variable is a dummy for the year 2004 to account for temporal variation in the incidence of piracy between elections in our dataset.

\subsection{Results}

Figure 3 presents a coefficient plot with two models of competitiveness and piracy in the 1999 and 2004 elections (see Table 1 for full results below). Model 1 includes the measure for victory margins in legislative elections. The coefficient is negative and significant, thus showing that piracy declines in proximity to less electorally competitive elections. This, in turn, supports Hypothesis 1. The results for controls are in line with expectations from the literature. Grids further away from the coast are less likely to experience piracy. We also find evidence of temporal and spatial dependence. Grids in years before elections are at greater risk of piracy. The spatial lag also is positive and significant, indicating spatial diffusion of piracy. Grids bordering the Malacca Straits likewise experience more piracy, as expected. Similar to findings for other crimes, we find that higher average temperatures increase piracy. We find no statistical significance for nighttime lights, although it is not clear that findings for economic opportunities from country-level studies have similar implications within states. It may be that poorer countries attract more individuals to

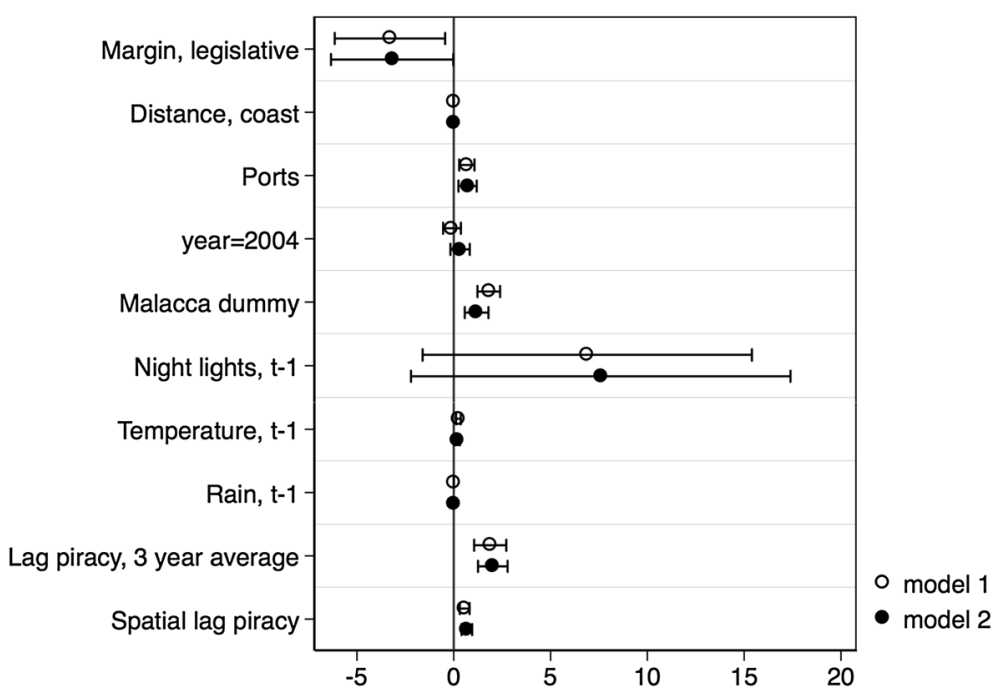

Fig. 3 Coefficient plot of elections and piracy in Indonesia, models 1-2 
piracy, but within such countries, pirates likely need to be close to areas of economic activity to find targets, i.e., ports with ships. The fact that the ports variable is positive and significant lends supports to this conjecture. We do not find an effect for rainfall.

In Model 2, we limit our dependent variable to piracy incidents in the year before elections (i.e., 1998 and 2003) and the election year itself (i.e., 1999 and 2004). Arguably, a post-election effect of political competitiveness on piracy should be conditional on whether the incumbent lost office. The coefficient for victory margins remains negative and significant, again showing that larger electoral margins are associated with less piracy. Hence, our results are not conditional on controlling for post-election incidents.

Hypothesis 1 indicates a direct effect of electoral competition on piracy, regardless of where piracy happens. Since piracy occurs at sea while elections take place on land, the effect of electoral competition on piracy nevertheless likely declines with distance. For piracy far removed from the coast, it becomes much more difficult to establish where the attacks originated and a link between electoral competition and piracy hence is less plausible. Expecting the effect of electoral competition to be stronger in grids closer to the coast, we therefore compare the effect of victory margins on piracy for close and far away distances. Figure 4 plots the predicted probability of piracy for grid-coast distances of 0 (grids adjacent to the coast) and $180 \mathrm{~km}$, which corresponds to values of one standard deviation below and above the mean.

The solid line in Fig. 4 indicates the effect of victory margins for grids adjacent to the coast (distance $=0$ ), while the dashed line shows the effect of margins for grids at one standard deviation above the mean of distance $($ distance $=180 \mathrm{~km})$. The results are consistent with our expectations: Larger election margins reduce piracy in grids contiguous to the coast (solid line), whereas the effect is absent for grids farther away (dashed line). The rug plot of victory margins at the bottom of the left panel also shows that this effect covers empirically relevant cases. Table 1 presents coefficients for both models.

Table 1 Event count regression of piracy and elections in Indonesia

\begin{tabular}{lll}
\hline & $(1)$ & $(2)$ \\
& $\mathrm{DV}=$ Piracy $t, t-1, t+1$ & $\mathrm{DV}=$ Piracy $t, t-1$ \\
\hline Margins, legislative & $-3.297^{*}(1.455)$ & $-3.184^{*}(1.611)$ \\
Distance to coast & $-0.012^{*}(0.002)$ & $-0.012^{*}(0.002)$ \\
Ports & $0.674^{*}(0.201)$ & $0.715^{*}(0.240)$ \\
Year = 2004 & $-0.091(0.234)$ & $0.327(0.254)$ \\
Malacca, dummy & $1.808^{*}(0.298)$ & $1.180^{*}(0.311)$ \\
Night lights & $6.895(4.339)$ & $7.592(5.000)$ \\
Temperature & $0.241^{*}(0.063)$ & $0.176^{*}(0.070)$ \\
Precipitation & $-0.001(0.001)$ & $-0.001(0.001)$ \\
Piracy lag, MA & $1.883^{*}(0.423)$ & $2.017 *(0.389)$ \\
Spatial lag piracy & $0.563^{*}(0.129)$ & $0.675^{*}(0.139)$ \\
$N$ & 4542 & 4542 \\
AIC & 1754.425 & 1372.624 \\
BIC & 1831.478 & 1449.677 \\
\hline
\end{tabular}

Standard errors clustered on grids in parentheses

$* p<0.05 ;{ }^{+} p<0.1$ 


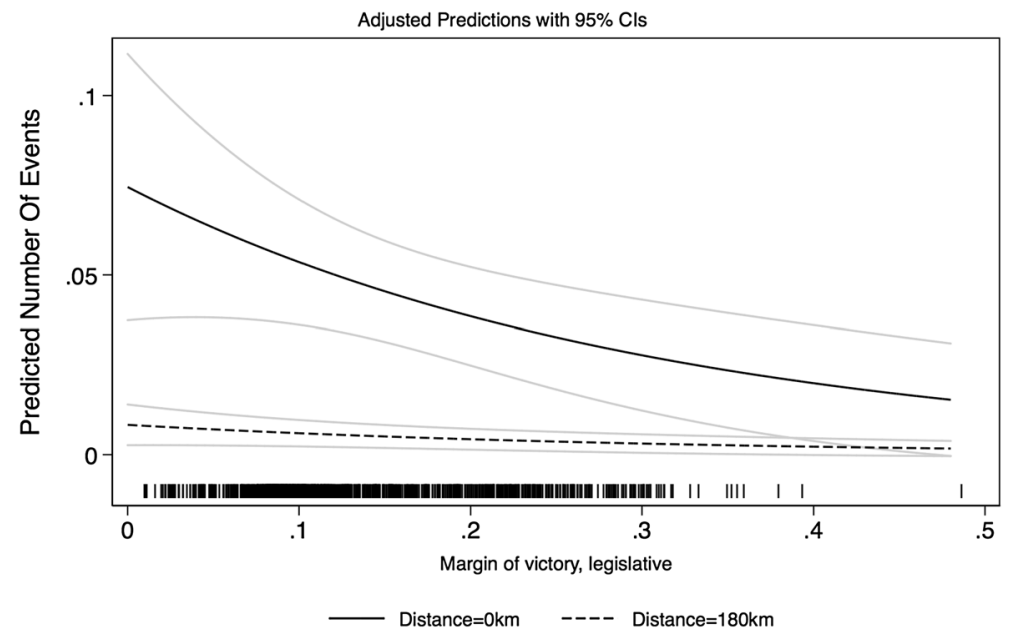

Fig. 4 Effect of victory margins on piracy, varying grid-coast distance \pm 1 SD (model 1)

\section{Robustness tests}

We present two sets of robustness tests. We first specify additional models for Indonesia to account for alternative explanations, other operationalizations of electoral competitiveness, dynamic controls, and an alternative definition of the dependent variable. Our second robustness test uses a cross-national, yearly research design to show that a relationship between electoral competitiveness and piracy is not limited to Indonesia.

\subsection{Additional model specifications for Indonesia}

Table 2 presents results for additional models. Models 3 and 4 assess an important alternative explanation for a relationship between electoral competition and piracy, which suggests that political elites, law enforcement, and the security apparatus are preoccupied with the electoral process and hence reduce their attention to crime during elections. This distraction argument implies that crime in electorally competitive areas increases not because criminals anticipate disruption of their activities or signal their influence, as we argue, but rather because actors usually involved in combating crime focus their attention elsewhere. While both explanations would expect a relationship between electoral competitiveness and piracy, claims about distraction also suggest that elites would shift their attention to the most contentious and unstable areas, in particular those experiencing political violence. ${ }^{13}$ If the distraction argument is valid, electoral competition should lead to more crime in areas where elites focus little attention on it (i.e., areas far from political violence), but reduce crime in areas experiencing political violence, where elites presumably pay attention. Conversely, if our arguments about disruption effects hold, we would expect that proximity to political violence has little effect on the relationship we hypothesized. Controlling for proximity to electoral violence should make it more difficult

${ }^{13}$ Models controlling for political violence also help to address whether our results simply pick up a more generally unstable environment in electorally competitive regions. 


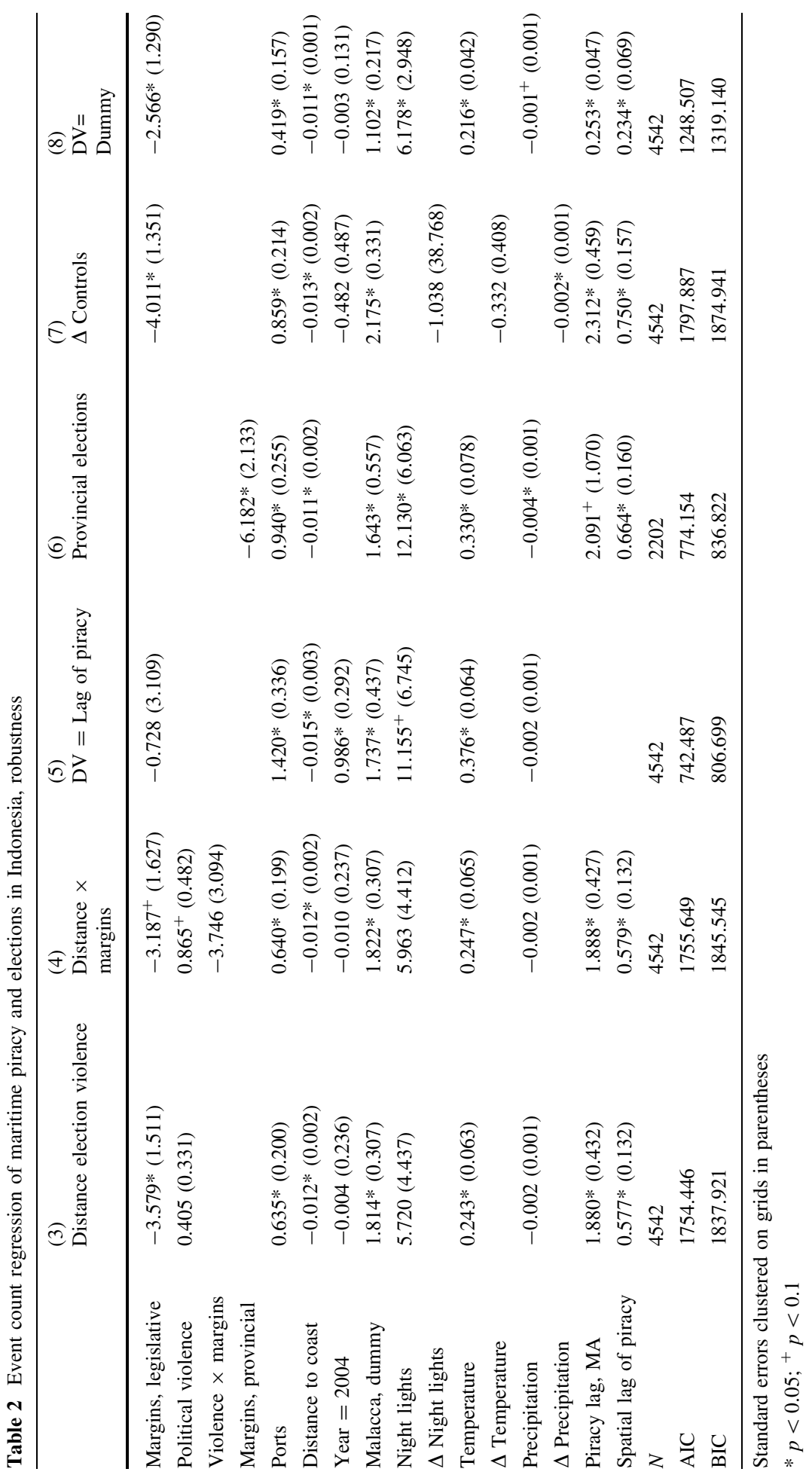


for the electoral competition-piracy relationship to survive since this variable is more consistent with the distraction argument.

In Model 3, we include a dummy variable indicating proximity to election violence on land. We use data from the Electoral Contention and Violence (ECAV) project (Daxecker and Amicarelli 2016) to calculate whether a grid is within $75 \mathrm{~km}$ of a land-based electoral violence event in 1999 or 2004 . We present two models, one in which we control for the proximity to political violence, and another in which we interact victory margins with proximity. As the results of estimating model 3 show, the margins variable remains negative and significant even when we control for proximity to election violence, which suggests that distraction does not fully explain the competition-piracy link. In Model 4, we also interact victory margins with proximity to election violence. Of concern to our inferences would be if the effect of electoral competition on piracy is strong in grids far away from political violence, but absent in grids experiencing such violence, since this would be most consistent with claims of distraction. The interaction term is not statistically significant, thus not supporting the alternative explanation.

Model 5 examines whether electoral competition captures preexisting regional conditions, correlated with victory margins. ${ }^{14}$ If, for example, regional differences in state capacity correlate with electoral competitiveness, those preexisting factors might explain the empirical relationships rather than our hypothesis. We examine this possibility indirectly by redefining our dependent variable to include only piracy events several years before elections (1995-1997 for the 1999 elections and 2000-2002 for the 2004 elections). We argue that election margins have an independent effect on piracy, rather than simply reflecting historical factors such as lower or higher state capacity in less or more electorally competitive regions. If our argument is correct, victory margins should have no significant effect on piracy occurring several years before. If on the other hand margins continue to have a negative and significant effect on piracy, they might indeed capture historical factors correlated with victory margins. As model 5 shows, the coefficient for victory margins is insignificant, thus making it unlikely that historical factors, rather than margins themselves, are responsible for the empirical relationship we establish in this article.

Model 6 includes a measure of electoral competitiveness in provincial rather than legislative elections. We are limited to 1999 data for provincial elections because we could not locate those data for 2004, which is why our main models use legislative election results. Theoretically, it makes sense to expect the strongest empirical relationship for elections with the most local implications, as our discussion of connections between pirates and local elites has emphasized. For the 1999 provincial elections, we therefore calculate the margin of victory, which ranges from 0.03 to 0.47 . As the results show, we find that larger margins reduce piracy in provincial elections, corroborating our findings from legislative elections.

\footnotetext{
14 An alternative explanation focuses on the demand for criminal violence by political elites. Similar to claims about election violence as a form of manipulation, a demand-centered argument would expect that political elites incite piracy to make their opponents appear incapable and influence voter's decisions at the ballot box. For example, Perouse de Montclos (2012, p. 536) describes how politicians in the Niger Delta hired pirates to demonstrate the federal government's and regional governor's inability to maintain order in the run-up to the 2011 general elections in Nigeria. Crucially, this argument hinges on voters evaluating candidates with respect to to their performances on crime. As we mention above, we do not think that citizens are preoccupied with crime early on in the democratization process and, moreover, piracy is a type of criminal activity less likely to prey on ordinary citizens. While we would like to confirm our intuition empirically, survey data on citizen perceptions of crime in Indonesia do not provide information on respondent location for the time analyzed herein (email correspondence with Asiabarometer staff).
} 
In Model 7, we include first differences of measures for night lights, temperature, and rainfall instead of yearly levels, thus capturing how changes in these controls could affect the rate of attacks, compared with static measures. Because of the lagged dependent variable, static measures make it difficult to assess our control variables' effects on piracy. We use data from the PRIO GRID to calculate first differences for controls. In Model 7, victory margins remain negative and significant. For first-differenced controls, only the increases in rainfall are significant, showing that such increases are associated with less piracy. Model 8 uses a dummy dependent variable instead of the count to ensure that the relatively small number of grids with a large number of piracy events and does not influence our results. In model 8 , the margins variable continues to be negative and significant.

\subsection{Cross-national analyses}

We present results from cross-national analyses to demonstrate that the elections-piracy relationship holds more generally than in the Indonesian case. These cross-national analyses have several disadvantages, including being limited to national elections, losing significant subnational variation in the competitiveness of elections, and aggregating piracy to the country-level. Furthermore, while we expect our empirical implications to hold most strongly in transitional periods, the cross-national dataset includes both transitional and routine elections in established democracies. For these reasons, we expect weak findings but hope to establish some support for Hypothesis 1. The unit of analysis in our crossnational analyses is the country-year.

We use data from MPELD to create our dependent variable, which is a count of piracy incidents attributed to each country per year. ${ }^{15}$ We use negative binomial estimation because the dependent variable is an event count with over-dispersion. Additionally, we use fixed-effects estimation to account for observational heterogeneity. Employing fixed effects also means limiting our sample to coastal states experiencing at least one piracy incident during 1993-2010. Our theoretical mechanism outlines how the incidence of competitive elections affects the strategic considerations of existing criminal actors rather than producing new criminal groups; hence it makes sense to presuppose piracy as a viable option.

Our main independent variables focus on electoral competitiveness. Our first independent variable is a dummy indicating whether a competitive election was held in a particular country-year. We lag elections by one year to capture increases in piracy in anticipation of competitive elections. Data for competitive elections come from the National Elections in Democracies and Autocracies dataset (NELDA) (Hyde and Marinov 2012). Second, we add data on the effective number of parties as a proxy for the competitiveness of the electoral system. Wilkinson (2006), for example, uses party fractionalization as an indicator of competitiveness. Data on the number of effective parties come from Teorell et al. (2015) and Bormann and Golder (2013). The variable is lagged by one year, so we do not estimate the effect of elections on fractionalization. While we would have preferred to use data on victory margins, they either are not available in existing

\footnotetext{
15 We assigned pirate incidents to states if they occurred within 12 nautical miles of coastlines, to the country from which the pirates originate (if indicated in the IMB report), or to the coastal country closest to the pirate incident for incidents beyond 12 nautical miles. We used ArcGIS to assign incidents to individual countries.
} 
Table 3 Cross-national event count regression of maritime piracy, 1993-2010

\begin{tabular}{lll}
\hline & $(9)$ & $(10)$ \\
& Elections dummy & Party fractionalization \\
\hline Competitive election & $0.087^{+}(0.045)$ & $0.072^{*}(0.033)$ \\
Party fractionalization & & $0.001(0.002)$ \\
Ports & $0.001(0.002)$ & $-0.012^{+}(0.007)$ \\
Government effectiveness & $-0.006(0.005)$ & $0.427(0.321)$ \\
Coastline, logged & $0.033(0.155)$ & $-0.046(0.267)$ \\
GDP per capita & $-0.180(0.136)$ & $0.566^{*}(0.198)$ \\
Population & $0.453^{*}(0.111)$ & $-0.040(0.080)$ \\
Temperature & $-0.017(0.061)$ & $0.011^{+}(0.006)$ \\
Precipitation & $0.011^{*}(0.002)$ & $0.009^{*}(0.003)$ \\
Lag of piracy, MA & $0.007^{*}(0.002)$ & 473 \\
$N$ & 1001 & yes \\
Country FE & yes & yes \\
Year FE & yes & 1072.368 \\
AIC & 2302.886 & 1168.028 \\
BIC & 2415.788 & \\
\hline$* 20.05 ;$ & &
\end{tabular}

$* p<0.05 ;{ }^{+} p<0.1$

datasets on elections (e.g., NELDA), or available only with lots of missing observations (e.g., V-Dem). ${ }^{16}$

We control for a variety of factors that likely also affect piracy, including state capacity, GDP per capita, the number of ports per country, population, coastline length, average yearly rainfall and temperatures, and temporal dependence. We use data on government effectiveness from the World Bank Governance Indicators to control for state capacity (Kaufmann et al. 2009). Data on per capita GDP and population also come from the World Bank. Port data are again from the World Port Index. Coastline length (in km) comes from the CIA Factbook and is time invariant. We control for climate factors with average temperatures and average precipitation; the information is taken from the World Bank. ${ }^{17}$ We control for temporal dependence with a three-year moving average of the dependent variable. Finally, we include year dummies to account for temporal heterogeneity. The independent variables are lagged by one year unless specified otherwise.

Table 3 presents results for fixed effects negative binomial regressions. In model 9, we include the dummy variable for competitive elections coded 1 for election years and 0 otherwise. We see a weakly significant positive effect of elections on piracy for this variable $(z=1.95)$. In model 10 , we enter the party fractionalization variable instead of the elections dummy. This variable is positive and significant, indicating that countries with more fractionalized party systems experience more piracy, which is consistent with our expectations.

\footnotetext{
16 After calculating victory margins with data from V-Dem (Coppedge et al. 2015), we retained only 182 observations.

17 http://data.worldbank.org/developers/climate-data-api.
} 


\section{Conclusion}

An emerging literature links elections to criminal violence, in particular homicides (Alesina et al. 2016; Hoelscher 2015; Moro et al. 2016; Villarreal 2002). Our paper is the first to examine whether electoral competitiveness creates or reinforces incentives for maritime piracy. An empirical focus on piracy has several advantages: Piracy constitutes a type of criminal activity that is more easily distinguishable from political violence than, for example, homicides; it allows for observing criminal activity rather than principally competition among criminal actors; and cross-national data that are spatially and temporally disaggregated are available for piracy.

We theorize that elections increase piracy because of disruption effects, expanding on existing theories focusing primarily on intergroup competition. Pirates, like other criminal actors, depend on agreements with local law enforcement agents, coast guards, or elected officials to maintain flourishing businesses. In consequence, the prospect of political changes brought about by competitive elections (and the possibility of changes in the governing regime) can induce pirates to increase criminal activity to signal their influence, compete with rival actors, and engage in piracy before new actors take office. Our empirical models use disaggregated data on electoral competitiveness and piracy for the 1999 and 2004 elections in Indonesia. As that nation's first democratic elections, they are well-suited for an empirical test of our arguments. The results show that close electoral contests increase the risk of piracy, particularly in grids close to the coast. These results remain consistent across a number of robustness tests. Importantly, we also find a positive effect of competitive elections on piracy in a sample of all nation-states around the globe experiencing at least one piracy incident. The evidence thus supports theories suggesting that elections increase criminal activity generally, while the scarcity of cross-national crime data limited previous work to single case studies.

These findings help put research positing a link between elections and non-political violence on more solid grounds. We establish a relationship for elections and piracy, a form of criminal activity not examined before. Our results also align with research on the connections between democratization processes and criminal violence (Grillo 2012). While that research has focused primarily on Latin America, we show that the adoption of competitive elections can increase crime in other nations and regions. Democratization may nevertheless have long-term positive implications for stability. While we demonstrate some short-term negative effects of the introduction of democratic processes, we expect their crime-inducing effects to fade over time. Once elections become routinized and citizens come to evaluate politicians on their performances in office, corruption and combating crime, the impacts of elections on crime should become weaker or even disappear.

Funding The authors acknowledge funding from Office of Naval Research (ONR Grant No. N00014-14-10050).

Open Access This article is distributed under the terms of the Creative Commons Attribution 4.0 International License (http://creativecommons.org/licenses/by/4.0/), which permits unrestricted use, distribution, and reproduction in any medium, provided you give appropriate credit to the original author(s) and the source, provide a link to the Creative Commons license, and indicate if changes were made. 


\section{References}

Aksoy, D. (2014). Elections and the timing of terrorist attacks. The Journal of Politics, 76(04), 899-913. doi: $10.1017 /$ S0022381614000504.

Alesina, A., Piccolo, S., \& Pinotti, P. (2016). Organized crime, violence, and politics. National Bureau of Economic Research. http://www.nber.org/papers/w22093. Accessed 22 June 2016

Amirell, S. E. (2008). Maritime piracy and raiding in Southeast Asia: local and global perspectives. In T. Chong (Ed.), Globalization and its counter-forces in Southeast Asia. Singapore: ISEAS Publishing.

Axbard, S. (2015). Income opportunities and sea piracy in Indonesia and extractive industries, production shocks and criminality. http://www.diva-portal.org/smash/record.jsf?pid=diva2:787097. Accessed 15 April 2016

Bailey, J., \& Taylor, M. M. (2009). Evade, corrupt, or confront? organized crime and the state in Brazil and Mexico. Journal of Politics in Latin America, 1(2), 3-29.

Berrebi, C., \& Klor, E. F. (2006). On terrorism and electoral outcomes theory and evidence from the IsraeliPalestinian conflict. Journal of Conflict Resolution, 50(6), 899-925.

Bormann, N.-C., \& Golder, M. (2013). Democratic electoral systems around the world, 1946-2011. Electoral Studies, 32(2), 360-369.

Brancati, D. (2014). Global elections database [computer file]. New York: Global Elections Database [distributor]. Accessed Jan 142016.

Chaturvedi, A. (2005). Rigging elections with violence. Public Choice, 125(1-2), 189-202.

Choi, N. (2007). Local elections and democracy in Indonesia: the Riau Archipelago. Journal of Contemporary Asia, 37(3), 326-345.

Collier, P., \& Vicente, P. C. (2011). Violence, bribery, and fraud: the political economy of elections in SubSaharan Africa. Public Choice, 153(1-2), 117-147.

Coppedge, M., Gerring, J., Lindberg, S. I., Skaaning, S.-E., Teorell, J., Altman, D., Bernhard, M., Fish, M.S., Glynn, A., Hicken, A. (2015). V-Dem [Country-Year/Country-Date] Dataset v5. Varieties of Democracy (V-Dem) Project.

Daxecker, U. E., \& Amicarelli, E. (2016). Electoral Contention and Violence (ECAV): A new dataset. Unpublished manuscript.

Daxecker, U. E., \& Prins, B. C. (2013). Insurgents of the sea: institutional and economic opportunities for maritime piracy. Journal of Conflict Resolution, 57(6), 940-956.

Daxecker, U. E., \& Prins, B. C. (2015a). The Maritime Piracy Location and Event Data (MPELD). Unpublished manuscript.

Daxecker, U. E., \& Prins, B. C. (2015b). Searching for sanctuary: government power and the location of maritime piracy. International Interactions, 41(4), 699-717.

Earl, J., Martin, A., McCarthy, J. D., \& Soule, S. A. (2004). The use of newspaper data in the study of collective action. Annual Review of Sociology, 30, 65-80.

Fjelde, H., \& Höglund, K. (2016). Electoral institutions and electoral violence in Sub-Saharan Africa. British Journal of Political Science, 46(2), 297-320.

Gaibulloev, K., \& Sandler, T. (2016). Decentralization, institutions, and maritime piracy. Public Choice, . doi:10.1007/s11127-016-0346-3.

Ghosh, A. (2006). Electoral cycles in crime in a developing country: evidence from the Indian states. http:// papers.ssrn.com/sol3/papers.cfm?abstract_id=910054. Accessed 2 Sept 2016.

Gordon, S. C., \& Huber, G. A. (2002). Citizen oversight and the electoral incentives of criminal prosecutors. American Journal of Political Science, 46(2), 334-351.

Gould, E. D., \& Klor, E. F. (2010). Does terrorism work? The Quarterly Journal of Economics, 125(4), $1459-1510$.

Grillo, I. (2012). El Narco: Inside Mexico's criminal insurgency. London: Bloomsbury Publishing.

Hafner-Burton, E. M., Hyde, S. D., \& Jablonski, R. S. (2014). When do governments resort to election violence? British Journal of Political Science, 44(1), 149-179.

Hastings, J. V. (2009). Geographies of state failure and sophistication in maritime piracy hijackings. Political Geography, 28(4), 213-223.

Hastings, J. V. (2012). Understanding maritime piracy syndicate operations. Security Studies, 21(4), 683-721.

Hastings, J. V., \& Phillips, S. G. (2015). Maritime piracy business networks and institutions in Africa. African Affairs, 114(457), 555-576.

Hoelscher, K. (2015). Politics and social violence in developing democracies: theory and evidence from Brazil. Political Geography, 44, 29-39.

Hyde, S. D., \& Marinov, N. (2012). Which elections can be lost? Political Analysis, 20(2), 191-210. 
Jablonski, R. S., \& Oliver, S. (2013). The political economy of plunder: economic opportunity and modern piracy. Journal of Conflict Resolution, 57(4), 682-708.

Kalyvas, S. N. (2015). How civil wars help explain organized crime-and how they do not. Journal of Conflict Resolution, 59(8), 1517-1540.

Kaufmann, D., Kraay, A., \& Mastruzzi, M. (2009). Governance matters VIII: Aggregate and individual governance indicators, 1996-2008 (SSRN Scholarly Paper). Rochester, NY: Social Science Research Network. https://openknowledge.worldbank.org/bitstream/handle/10986/4170/WPS4978.pdf?sequence=1. Accessed 11 Mar 2014

Kollman, K., Hicken, A., Caramani, D., \& Backer, D. (2011). Constituency-level elections archive (CLEA). Ann Arbor,MI: Center for Political Studies, University of Michigan.

Meloni, O. (2012, June 19). Is there an electoral-motivated crime rate cycle? evidence from Argentina. MPRA Paper. https://mpra.ub.uni-muenchen.de/40177/. Accessed 12 Jan 2016

Moro, F. N., Petrella, A., \& Sberna, S. (2016). The politics of mafia violence: explaining variation in mafia killings in southern Italy (1983-2008). Terrorism and Political Violence, 28(1), 90-113.

Murphy, M. N. (2009). Small boats, weak states, dirty money: the challenge of piracy. New York: Columbia University Press.

Newman, L. S. (2012). Do terrorist attacks increase closer to elections? Terrorism and Political Violence, 25(1), 8-28. doi:10.1080/09546553.2013.733247.

Pérouse de Montclos, M.-A. (2012). Maritime piracy in Nigeria: Old wine in new bottles? Studies in Conflict \& Terrorism, 35(7-8), 531-541.

Salehyan, I., \& Linebarger, C. (2014). Elections and social conflict in Africa, 1990-2009. Studies in Comparative International Development, 50(1), 23-29.

Shortland, A., \& Varese, F. (2014). The protector's choice: an application of protection theory to Somali piracy. British Journal of Criminology, 54(5), 741-764.

Shortland, A., \& Varese, F. (2015). State-building, informal governance and organised crime: the case of Somali piracy. Political Studies, forthcoming, doi:10.1111/1467-9248.12227.

Slater, D. (2004). Indonesia's accountability trap: party cartels and presidential power after democratic transition. Indonesia, 78, 61-92.

Staniland, P. (2014). Violence and democracy. Comparative Politics, 47(1), 99-118.

Storey, I. (2008). Securing Southeast Asia's sea lanes: a work in progress. Asia Policy, 6(1), 95-128.

Teorell, J., Dahlberg, S., Holmberg, S., Rothstein, B., Hartmann, F., \& Svensson, R. (2015). The quality of government standard dataset, version jan15. The Quality of Government Institute: University of Gothenburg.

The Nautilus Institute. (2007). The roots of piracy in Southeast Asia. Nautilus Institute for Security and Sustainability. http://nautilus.org/apsnet/the-roots-of-piracy-in-southeast-asia/. Accessed 16 Jan 2016

Tollefsen, A. F., Strand, H., \& Buhaug, H. (2012). PRIO-GRID: a unified spatial data structure. Journal of Peace Research, 49(2), 363-374.

Villarreal, A. (2002). Political competition and violence in Mexico: hierarchical social control in local patronage structures. American Sociological Review, 67(4), 477-498.

Wagner, S. (1999). Survey of the Indonesian electorate following the June 1999 elections. International Foundation for Election Systems, August. http://www.ifes.org/sites/default/files/indonesia_public_ opinion_2000_2.pdf. Accessed 2 Sept 2016

Welsh, B. (2008). Local and national: keroyokan mobbing in Indonesia. Journal of East Asian Studies, 8(3), 473-504.

Wilkinson, S. I. (2006). Votes and violence: Electoral competition and ethnic riots in India. Cambridge University Press.

Wilson, D. I. (2006). Continuity and change: the changing contours of organized violence in post-new order Indonesia. Critical Asian Studies, 38(2), 265-297. 